\title{
Imágenes, trauma, memoria: miradas del pasado reciente en obras de Patricio Guzmán, Adriana Lestido y Gustavo Germano
}

\section{Fernández Bravo, Álvaro}

Resumen:

Este artículo propone comparar representaciones del pasado traumático reciente en Argentina y Chile a partir de los testimonios recogidos en el filme Nostalgia de la luz de Patricio Guzmán, en la serie de fotografías Lo que se ve (1979-2007) de Adriana Lestido y en dos fotomontajes de Gustavo Germano perteneciente a la serie Ausencias. Tanto el filme como las imágenes evocan los vestigios ausentes (los cuerpos ausentes), ejecutados por las dictaduras militares en Argentina y Chile, a partir de la evocación y presencia de los familiares sobrevivientes. El trabajo propone analizar el régimen temporal

Cuadernos del Centro de Estudios de Diseño y Comunicación Nº 61

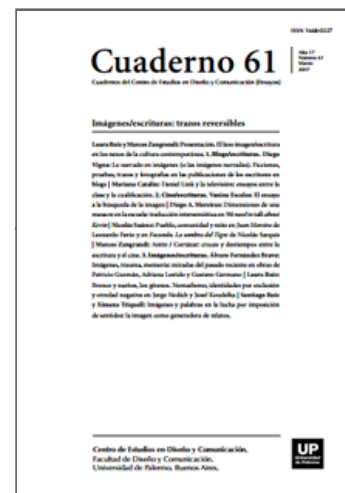

ISSN: 1668-0227

Imágenes/escrituras:

trazos reversibles

Año XVII, Marzo 2017, Buenos Aires, Argentina | 176 páginas

descargar PDF ver índice de la publicación

Ver todos los libros de la publicación

compartir en Facebook traumático de los cuerpos desaparecidos y su contraste con la memoria afectiva, examinar la condición temporal iterativa heterocrónica del trauma en los regímenes escópicos sudamericanos contemporáneos e interrogar los usos del archivo mnemónico como intervención-instalación visual.

Palabras clave:

memoria - tiempo - imagen - cine - fotografía.

$\left(^{*}\right)$ Investigador del CONICET e investigador afiliado en la Universidad de San Andrés, Argentina, donde enseña cursos de posgrado. Obtuvo su Licenciatura en Letras en la Universidad de Buenos Aires, su maestría y doctorado en la Universidad de Princeton, Estados Unidos y realizó su posdoctorado en la Universidad Federal de Minas Gerais, Belo Horizonte, Brasil. Fue profesor las universidades de Temple (Estados Unidos), de Buenos Aires (UBA), de San Andrés, Mar del Plata, Rosario, Salta, en New York University Buenos Aires, cuya sede dirigió entre 2008 y 2013 y en la Universidad Católica de Río de Janeiro. 
El problema de la memoria del pasado reciente y en particular la representación de la violencia estatal durante las dictaduras de los setenta en Argentina y Chile, ha convocado distintas intervenciones desde la producción simbólica contemporánea. El propósito de este artículo es explorar algunos caminos recorridos en obras de arte visuales realizadas por cineastas y fotógrafos chilenos y argentinos para responder a la pregunta por la formación de la memoria colectiva e interrogar las huellas de la violencia estatal de los años setenta. ¿Cómo representar el cuerpo ausente de los desaparecidos? ¿Qué recursos o estrategias emplear para hablar de alguien que ya no está, pero cuyos vestigios continúan perturbando la memoria de sus deudos y pares en el presente? ¿Qué tipo de relaciones es posible reconocer entre los restos del pasado traumático y el presente que lo evoca en las imágenes experimentadas para representarlo? Estas preguntas pueden multiplicarse y complejizarse si examinamos los trayectos recorridos por artistas visuales que exploran distintas plataformas para imaginar formas de representar el pasado reciente.

Mi trabajo partirá de tres soportes que tomaré para abordar esta cuestión: el film Nostalgia de la luz, de Patricio Guzmán (Alemania, Francia, Chile, 2010), algunas imágenes de la exhibición retrospectiva Lo que se ve (19792007) de Adriana Lestido, montada en el Centro Cultural Recoleta de Buenos Aires en 2008 y dos fotografías de la serie Ausencias (2006) de Gustavo Germano, exhibida en diferentes espacios de Argentina y Europa.

Los tres artistas elegidos comparten un interés por la violencia estatal de los setenta y coinciden en algunos caminos y estrategias para hablar de ella. Quiero concentrarme en tres problemas que enunciaré primero de un modo más abstracto y, luego, en diálogo directo con las imágenes. Este trabajo tomará como punto de partida las preguntas disparadas a partir de la memoria del pasado reciente pero también procura recuperar, en particular a partir de Guzmán y Lestido, referencias a un tiempo más amplio. Ambos artistas amplían su rango de interés más allá de los años de la década de 1970, tanto hacia el siglo XIX como a un pasado remoto indígena (Guzmán) y en el caso de Lestido, al mundo de las cárceles de mujeres en la post dictadura en la Argentina. De algún modo la exploración del pasado abre canales a tiempos diversos que comparten con la violencia del terrorismo de Estado, genealogías y ecos contemporáneos.

El primer problema es la relación temporal de la imagen con el presente y con el pasado.

Quiero comenzar examinando dos regímenes asimétricos pero con puntos de convergencia: el régimen de la imagen y el régimen de la memoria. El anacronismo que encierra toda imagen puede pensarse a partir del régimen de la memoria que, como sabemos a partir de los numerosos trabajos que se han escrito sobre la cuestión en los últimos años (Didi- Huberman, Koselleck, Hartog, Huyssen, Richard, Sarlo), provee un territorio a la vez inestable y fructífero donde memoria y olvido ya no pueden continuar reconociéndose como dos dimensiones antagónicas sino más bien como componentes de un mismo "trabajo".

La memoria siempre opera con una unidad ausente, de modo que los casos que estudiaré no difieren del mecanismo más o menos convencional del acto de recordar, esto es, evocar algo ausente mediante un acto de imaginación. Memoria e imaginación, esto es, memoria e imago, funcionan antes como dispositivos aliados que como mecanismos desiguales. 
El régimen temporal de la memoria ha sido comparado con el del montaje cinematográfico a partir de su articulación en fragmentos que no se corresponden con una totalidad continua y compaginan tiempos heterogéneos. La noción de "trabajo de la memoria" supone una dimensión no estática sino, por el contrario, en transformación continua y alteración iterativa (Derrida). A diferencia del discurso histórico que persigue una continuidad o duración, la memoria trabaja con cortes y suturas, como si "juntar[a] miembros desperdigados" según lo señala Nelly Richard (2010, p. 153)-. Pensada entonces como una superficie horadada e interrumpida, la memoria puede ser explorada en relación con las imágenes de la violencia estatal acontecida en los años setenta en el Cono Sur y las articulaciones contemporáneas que continúan elaborando imágenes para abastecerla.

La memoria, a diferencia del discurso histórico, opera con partes y fragmentos de contornos inestables, cambiantes, capaces de alterar el sentido de una totalidad siempre provisoria; la memoria también suele valerse de imágenes que, a diferencia de las imágenes visuales de una fotografía o un film, son intangibles, difusas y mutantes. ¿Cuán firmes son las imágenes alojadas en la memoria? Como observaba Kracauer hace ya casi cien años, también las imágenes de una fotografía, al atravesar el tiempo, cambian, envejecen y muestran su obsolescencia: ni siquiera el soporte fotográfico permanece inmune al paso del tiempo, y su vínculo con la historia es provisorio y cambiante.

Memoria e imagen comparten entonces esa condición de superficies perforadas y dinámicas, porosas a la infiltración de nuevos hallazgos y permeables a los cambios del tiempo.

Acaso esa misma apertura y porosidad convierte a memoria e imagen en superficies aptas y compatibles para elaborar la violencia estatal sudamericana de los setenta, un archivo poblado de lagunas y, todavía, en una fase de expansión.

Como sabemos (Feld y Sites Mor; García y Longoni) el debate sobre la existencia de imágenes de los desaparecidos y fotografías de los centros clandestinos de detención y exterminio continúa todavía abierto. En principio las dictaduras procuraron borrar no solo los cuerpos sino también los restos visuales o documentales de la acción represiva. Existen algunos archivos parciales de fotografías contrabandeadas por detenidos en los centros, pero la evidencia material es escasa. No obstante, las imágenes pueden resistir y de hecho muchas de ellas todavía continúan resistiendo (amén de que puedan encontrarse otras en un futuro) a las políticas amnésicas de los Estados burocráticos autoritarios como los denominó Guillermo O’Donell. El régimen anacrónico de la imagen puede pensarse así como uno que excede y sobrevive la observación presente y se coloca por lo tanto en una temporalidad más amplia que quien la observa1.

Más allá de este debate sobre las imágenes invisibles de las dictaduras del Cono Sur, me interesa ir un poco más atrás, para detenerme en lo invisible que forma parte de toda imagen. Este es el segundo problema que me interesa interrogar. Como sabemos, el fuera de campo (o fuera de cuadro, cuando hablamos de una fotografía) es un elemento constitutivo y significante, tanto en el cine como en la fotografía, de toda imagen. Se trata de un componente que no solo articula lo mostrado con lo que no se ve de la imagen pero resulta sugerido, sino que altera el sentido de lo visible a partir de algo que está ausente; esa posición exterior e intangible permite suponer también una relación heterocrónica donde nuevos sentidos pueden añadirse a la imagen con el aporte de un espectador capaz de convocar otros sentidos y reponer lo que la fotografía misma exhibe y sugiere (Beceyro, Cadava, Rancière). Hay un exterior a la imagen que habla sobre ella y de la cual ella depende para mostrar lo 
que dice; siempre resulta imprescindible examinar las relaciones de la imagen con sus bordes exteriores y con lo que no está dentro del marco pero que resulta aludido desde él mismo.

En cierto sentido, el fuera de cuadro trabaja con una ausencia que tiene un poder significante que puede compararse con el problema del cuerpo ausente que las imágenes del pasado reciente enfrentan. Esos cuerpos no están, pero son evocados por el fuera de cuadro y convocados por la imagen: se hacen presentes desde el pasado, esto es, emergen a partir de la intersección y contaminación heterocrónica de pasado y presente. De este modo, los retratos de los desaparecidos que aparecen en el film y en las fotos que analizaré se reconocen por el modo en que son exhibidos y por lo que su exhibición reclama. Se trata de imágenes comunes, tomadas a menudo de documentos o de fotografías convencionales empleadas por los familiares que piden por las víctimas de la violencia estatal.

No obstante, la función de pedido y reclamo se vuelve un componente central del fuera de cuadro por su posición en carteles, muros y espacios de protesta pública. Los rostros funcionan como marcas de la memoria colectiva que interrumpen los espacios públicos y fracturan el tiempo lineal: traen a alguien que viene de otro tiempo pero nos interpela a nosotros en el presente.

Me interesa concentrarme, entonces, en cómo en el caso específico del Cono Sur, la memoria del pasado opera bajo un régimen que podemos pensar en paralelo con una economía escópica. Si la memoria distorsiona, altera y modifica las siluetas de aquellos a quienes evoca, y también opera en forma selectiva, privilegiando ciertos recuerdos y relegando otros. Observamos huellas de este procedimiento en la evocación de los setenta a través de imágenes que tienen una fuerte dependencia de espacios y huellas locales, muchas de ellas evocadas en el fuera de cuadro (hay algo que la imagen señala o indica solo parcialmente pero que el espectador debe reponer). Las imágenes están situadas en el espacio y guardan un vínculo con el lugar a donde quedan asociadas: el campo de concentración, la cárcel, la celda, el centro de tortura; los lugares adquieren una dimensión aumentada y dinámica que actúa como suplemento de la imagen.

Aunque como toda memoria, la de los desaparecidos está perforada y sesgada por un hiato, el de la misma ausencia de los cuerpos, es por esas perforaciones que circula el pasado que emerge en el presente y el presente que interviene el pasado. Una economía traumática e iterativa de memorias que circulan bajo parámetros visuales (como cuerpos evocados) funciona así estableciendo una relación entre el presente de la evocación y el pasado evocado, asociado con los últimos recuerdos (visuales, fotos) de los desaparecidos.

Si bien puede parecer que ese vínculo temporal es estable, no lo es. Las imágenes (que existen y algunas de las cuales son producidas en el presente a partir de la ausencia) cambian y ese cambio puede relacionarse con el tercer elemento formal en el que quiero detenerme: el trauma como régimen iterativo. El trauma corresponde a un circuito temporal sin fin, recurrente pero que, en su economía de repetición, no alcanza una terminación, porque la misma definición de trauma supone un recuerdo que no logra aplacarse y regresa en la consciencia del sujeto que recuerda (Hirsch; Huyssen). Sin embargo, es posible reconocer que el retorno del recuerdo no lo convoca idéntico a sí mismo cada vez, sino que produce cambios. El trauma es "esa memoria que regresa en un régimen rítmico y sin progreso" pero que en su itinerario repetitivo puede traer nuevos elementos. Me interesa reconocer esos cambios en la memoria, algunos de los cuales resulta posible reconocer en el film de Guzmán y en las fotografías de Lestido y Germano. 
Lo que me interesa resaltar es que el trabajo de la memoria continúa alterando la silueta de esas imágenes en el mismo acto de la evocación, motivado en parte por una voluntad de desposesión y reapropiación de los cuerpos (Bhabha). Los cuerpos no permanecen intactos. De este modo, el presente interviene en el pasado, viaja hacia él y lo altera al convocarlo y extraerlo del arcón (el archivo, la excavación) para exhibirlo (Benjamin). Ni el recuerdo ni el acto de recordar permanecen inmunes en esta intervención temporal, sino que son alterados mutuamente cuando quien evoca "viaja" al pasado para extraer de él una imagen que lo retrotrae a ese tiempo alejado y al regresar, altera la materia de la memoria. Ese "retro-traer" implica un viaje en dos direcciones, hacia el pasado primero y hacia el presente (futuro del pasado) después que sella el vínculo con el pasado y donde, a la vez, se (entre)mezclan (y median) dos (o tres) tiempos. No hay entonces un pasado aislado, encapsulado e inmune al presente; presente y pasado se tocan y contaminan, dependen el uno del otro, sus dominios han perdido autonomía. Las imágenes que resultan de esta negociación son así compuestos híbridos, impuros y en proceso de contaminación; se trata de dislocaciones, ya que no se ubican en un tiempo nítido, sino en uno donde el presente perturba al pasado y el pasado perturba al presente.

La relación entre pasado y presente queda así mediada por la imagen-memoria que supone un torbellino (DidiHuberman, p. 110). Aparece, así, una intersección anacrónica en que pasado y presente resultan entrelazados y ya no responden a una secuencia discursiva como la que caracteriza al régimen escriturario. Pasado y presente quedan de este modo apartados de la estructura lineal de la historia cronológica. Las mujeres que buscan a sus familiares en el desierto de Atacama, como en la imagen reproducida a continuación, persiguen un cuerpo y una respuesta para su búsqueda pero están atrapadas en una relación heterocrónica donde el tiempo resulta central, algo que el film detecta con rapidez. No buscan completar un fragmento del pasado ausente, intentan alterar el pasado con una memoria producida en el presente que, al incrustarse en el tiempo, produce una transformación radical. Lo que ellas encuentran -los restos óseos en los que me detendré en un momento- opera como una aparición, una imagen-síntoma que altera el curso regular de la representación (Íbid., p. 44) (Imagen 1).

Los familiares-supervivientes funcionan también como agentes de la supervivencia de las imágenes: son casi siempre mujeres que se aferran a la memoria de los desaparecidos, una memoria que siguen excavando, a la que añaden nuevos datos, que enriquecen con otras pruebas o vestigios del pasado (como los restos óseos localizados en el desierto-museo) o que simplemente en el acto de preservar y "poner en acto" las imágenes, las cambian al volverlas cada vez más arcaicas, referentes fijos de un tiempo que se aleja. Esta operación de memoria que florece y cambia, guarda paralelos con la imagen (o fotografía) del pasado.

Ambas "trafican" entre dos (o más) tiempos y el producto de esa mediación supone una transformación: las imágenes envejecen, no permanecen idénticas, porque evocan referentes que, aunque aparentemente estáticos, también cambian2. "Todo ocurre en el pasado" dice el astrónomo Gaspar Golaz entrevistado por Patricio Guzmán en Nostalgia de la luz, porque el presente no existe, es una ilusión que dura una milésima de segundo y es de inmediato deglutido por el apetito insaciable del tiempo, que todo lo convierte en pasado.

Sin embargo, vale la pena aquí detenerse en los casos puntuales que estudiaremos. ¿Qué ocurre entonces con las fotos de los desaparecidos? ¿Cómo leer los rostros congelados pero recurrentes, que nos miran desde el pasado? Creo que hay una parte de ese analogon que perturba la obsolescencia: el cuerpo del sujeto contra el que la imagen podría contrastarse (como un edificio o una habitación donde se reconocen muebles, luz, marcas temporales de época) ya no está. Su trayectoria en el tiempo se interrumpió. Y eso lo convierte en un signo sin referente. Señala a alguien ausente y cuyo cuerpo o paradero se desconoce pero que quedó sesgado de una 
continuidad que los testigos-familiares reponen cada vez que lo buscan. De algún modo, el régimen temporal está cercenado de una parte, la que permite reconocer el paso del tiempo sobre un cuerpo, y es esa ausencia la que se vuelve más evidente en las obras que trabajan este problema.

Es la perforación del pasado (la abducción de un sujeto que ha sido extraído del flujo temporal dejando tras de sí la huella de un vacío) la que encuentra un reflejo en el flujo de la memoria.

¿Cómo entender la operación de sutura de pasado y presente? ¿Hay tal operación? ¿De qué modo se "cosen" tiempos a los que les falta un fragmento? Lo que corresponde pensar es en qué régimen temporal incluir a esas imágenes (existentes o producidas) que, aunque intervienen sobre el presente, están hablando del pasado.

Como dije, la imagen tiene una vida más larga que sus observadores. Ese excedente de vida la ubica en un régimen temporal diferente de las personas que la miran. Y la memoria está perforada de pasado, que es en rigor, como dice Gaspar Golaz, el tiempo hegemónico en el que todo ocurre.

\section{Cuerpos celestes, cuerpos terrestres}

"La historia no es exactamente la ciencia del pasado porque el 'pasado exacto' no existe" (Georges DidiHuberman, Ante el tiempo) Me gustaría continuar ahora llevando estas reflexiones de espíritu más bien teórico para ver cómo funcionan con ejemplos visuales observados desde más cerca.

Mi primer objeto será la película de Guzmán que examinaré a partir de objetos que atraviesan el tiempo y de los cuerpos considerados como objetos. La ausencia de los cuerpos opera de un modo singular en el film y permite elaborar sobre la crisis en la cronología lineal que ocurre cuando se produce el hallazgo de los huesecillos pertenecientes a los detenidos. El film opera con una noción de montaje que se abastece de una posición intermedia: el desierto y el cosmos son los dos telones de fondo contra los cuales se recorta el relato. El desierto alberga huellas de distintos pasados, algunos más remotos, como los dibujos indígenas grabados en las piedras, otros más próximos, como el campo de concentración de Chacabuco, que refiere dos momentos del pasado reciente y decimonónico.

Opera a partir de condiciones climáticas que preservan a las cosas del deterioro debido a la extrema sequedad. Ambos pasados, el decimonónico y el de los años setenta, introducen una reflexión filosófica y metafísica sobre el tiempo y el presente, ese tiempo inexistente.

Hay un plano del documental-ensayo Nostalgia de la luz de Patricio Guzmán que muestra un conjunto de cucharas colgadas en una habitación del campo de concentración de Chacabuco, el más grande centro de detención de la dictadura de Pinochet que funcionó a su vez como una mina en el siglo XIX. Las cucharas se mueven y hacen un sonido metálico, rítmico, como si formaran parte de una instalación vanguardista. Detrás de las cucharas suspendidas se perciben las ruinas del campo, los restos de construcciones de madera desvencijadas, al borde del colapso. Hay incluso restos de ropa, zapatos de cuero horadados por el tiempo, telas raídas por el tiempo. No hay seres humanos, no hay vida, solo el viento y el paisaje desolado del desierto de Atacama, donde transcurre la mayor parte del film. El sonido de las cucharas herrumbradas, de origen incierto (pueden haber pertenecido tanto a los obreros de la antigua mina como al campo de concentración, el film no lo aclara), el sonido de las cucharas movidas por el viento, decía, en el paisaje desolado del campo, 
parece un mensaje enviado desde un punto remoto del pasado, un sonido equivalente al de las estrellas auscultadas por los astrónomos con los telescopios gigantes instalados en el desierto. Es solo un conjunto de objetos comunes y arcaicos movidos por el viento, un resto que evoca la presencia humana en el campo-mina que envía su tintineo desde un punto remoto del pasado hacia el presente y deja el sonido vibrando en el espacio vacío del desierto de Atacama.

¿Cómo leer esa breve secuencia cinematográfica que condensa el cruce temporal del régimen de explotación laboral minero decimonónico, también evocado en fotografías de archivo en el film, con el campo de concentración más grande del régimen de Pinochet y con la observación astronómica? ¿Qué significa esa imagen donde un tiempo remoto y el presente se intersectan e interpelan al espectador? De algún modo los tres tiempos que participan de la película, el tiempo futurista (aunque como dice uno de los científicos, su tarea no examine el futuro sino más bien el pasado del cosmos que llega hasta nosotros desde tiempos remotos), el tiempo pasado de la mina y el pasado reciente de la dictadura, esos tres tiempos convergen en Chacabuco.

El film de Patricio Guzmán plantea un conjunto de preguntas que tienen como uno de sus ejes el pasado reciente y la experiencia traumática de la violencia estatal durante la dictadura de Pinochet. Pero el documental inserta ese momento en el marco de una reflexión más abarcadora sobre el tiempo histórico, los modos de aproximarnos a él y representarlo.

"El presente no existe" dice Gaspar Galaz, el joven astrónomo entrevistado en su oficina del observatorio en el documental.

A diferencia de consideraciones contemporáneas que asignan al presente una dimensión hiperbólica (Hartog, Huyssen), los astrónomos y arqueólogos que trabajan en el desierto de Atacama parecen vivir en un pasado expandido localizado en la superficie intemporal del desierto, un espacio que preserva los objetos de la corrosión temporal y desde el cual es posible viajar en el tiempo hacia un pasado remoto en el que se formaron las galaxias.

Así, la memoria para ellos "es un gran libro abierto" donde es posible leer las huellas de otros tiempos desde el presente. El presente está (en el) desierto, porque desde allí hay condiciones privilegiadas para viajar en el tiempo.

Me gustaría comenzar entonces con las cosas, como las cucharas que envían su sonido intemporal y son rescatadas en el film sin mayores comentarios. Las cucharas suspendidas en el aire, intactas, solo muestran lo que son: instrumentos de alimentación, cosas de uso cotidiano, sin valor, que fueron empleadas para comer en algún punto del pasado. Las cucharas son testimonio de que un grupo de personas pasó por allí, se alimentó y se valió de ellas para subsistir.

La memoria de las cosas comunes es una plataforma para examinar el pasado y procurar entenderlo y también para recuperar las preguntas que ese libro temporal dispara -que tiene una estructura discursiva y participa, en el régimen iconográfico del cine, de un régimen lingüístico-, aunque las respuestas no vengan por sí solas sino que sean el fruto de una "excavación" (Benjamin) donde el énfasis está más en el medio (el desierto donde se excava y el desierto que preserva) que en el resultado (la pieza arcaica encontrada) de esa empresa. Para Guzmán, tomar algo común o cualquier cuerpo terrestre: una radio vieja, los muebles de una casa común de 
Santiago, como los que se exhiben en el comienzo del film cuando el director evoca un pasado alejado del trauma, anterior al golpe y al gobierno de la Unidad Popular, son recursos para expandir el régimen temporal de la memoria y usar algo cualquiera, un cualquiera para mirar hacia los tiempos múltiples que la memoria evoca y emplea para navegar el presente. Esas cosas comunes funcionan como disparadores para pensar el pasado y habilitan un flujo que atraviesa el film.

Quisiera ahora moverme ahora hacia las mujeres de Calama, las protagonistas del film que encarnan esa búsqueda sin fin por reconstruir el paradero de sus deudos asesinados por la dictadura de Pinochet: hermanos no enterrados (como Antígona), esposos asesinados, familiares desaparecidos cuyos restos persiguen en el desierto. El film observa esos cuerpos destituidos, desmembrados y es testigo, incluso, de la recuperación de un cuerpo oculto.

Las condiciones atmosféricas de extrema sequía hacen que los cuerpos se preserven y no se descompongan.

Los huesecillos funcionan como fragmentos que permiten hablar de cadáveres ausentes, probablemente arrojados al mar para destruir evidencias de los crímenes. El film detecta allí una relación entre el calcio de los fragmentos óseos que las mujeres de Calama usan para intentar reconstruir el destino de sus deudos, y el calcio que está en las estrellas y que los astrónomos miden para obtener datos sobre la antigüedad y características de los cuerpos celestes. Cuerpos terrestres y cuerpos celestes quedan unidos por el calcio y ambos exhiben en ese vector biopolítico, que como observa Gabriel Giorgi, "pone en serie los restos de los cuerpos con las estrellas que se investigan desde los observatorios” (Giorgi, 2014, p. 222) (Imagen 2).

En efecto, si el film tiene como eje central la búsqueda de los restos (fragmentos) del cuerpo- pasado -un trabajo de la memoria que altera y enriquece la historia, crea conocimiento, completa vacíos y restituye fragmentos-, la operación también proyecta la reflexión más allá de la masacre puntual de la dictadura de Pinochet y, de un modo que podemos comparar con la fotografía de Lestido que veremos al final, permite pensar en cómo el trauma reverbera y tiene réplicas en otros momentos históricos. Excavar el pasado reciente hace aflorar otras presencias perturbadoras de tiempos heterogéneos: la de los indígenas que dejaron huellas, grabados, pinturas rupestres en las rocas y fueron exterminados por el Estado chileno y la de los mineros del siglo XIX, que vivieron en Chacabuco y dejaron sus cuerpos en el trabajo brutal de la explotación minera del desierto. Ambos referentes, indígenas y mineros evocan otras formas de violencia estatal que se conectan con la política represiva del régimen militar en la figura del campo de concentración. Chacabuco alberga restos y memorias no sólo de los años setenta sino de otros períodos de despojo y explotación capitalista. El acceso a esa memoria se da por imágenes, las fotos de la mina y los dibujos indígenas, y por cosas: piedras (sobre las que permanecen los dibujos) y los restos del campo (de concentración y de explotación minera).

Los huesecillos permiten a Vicky Saavedra entender qué ocurrió con su hermano Pepe, José Saavedra González, secuestrado y asesinado por la dictadura de Pinochet. Ella recupera un pie, un zapato, un calcetín y algunos fragmentos óseos del cuerpo de su hermano, según narra en el film. Su cuerpo, presumiblemente enterrado en una fosa común, fue hipotéticamente luego removido con una topadora para borrar rastros de los crímenes de Estado y arrojarlo al mar. Pero en esa remoción algunos extremos de los cuerpos (pies, cabeza) cayeron y quedaron desperdigados y conservados en el aire seco del desierto, donde las mujeres de Calama lograron recuperar algunos fragmentos. A través del pie de Pepe, Vicky reconstruye algo de lo que busca: una imagen más completa se arma a partir de un fuera de campo: el pie, el zapato, indican la identidad de quien ella 
está buscando y permiten componer una versión conjetural de su destino y su muerte. La excavación, sin embargo, no cesa con el hallazgo. Las mujeres continúan buscando porque el trauma nunca se termina, mantiene su régimen iterativo de excavación sin fin, funciona como un trabajo que no se contenta ni finaliza. El trabajo de la memoria, como sugiere Benjamin (2005[1932]), vuelve siempre a recomenzar, porque es un medio, esto es, un estado en sí mismo en el que la memoria habita y opera, y no un fin.

Lo que la búsqueda genera son más imágenes que alteran la memoria y la amueblan con nuevas imágenes. La relación de los cuerpos con el presente es dinámica: esos cuerpos producen y alteran las imágenes existentes y permiten construir (y acaso elaborar) el duelo de la pérdida. Vicky Saavedra puede ahora estar un poco más tranquila, aunque mantenga todavía memorias perturbadoras sobre el paradero de su hermano.

\section{Potencia del ausente}

Los dos últimos ejemplos en los que me voy a detener provienen ambos del campo de la fotografía. Se trata, como anuncié, de tres imágenes de la fotógrafa Adriana Lestido mostradas en la exhibición retrospectiva de su obra realizada en 2008 y de dos fotomontajes de Gustavo Germano que se exhibieron por primera vez en 2008. Las dos exhibiciones tuvieron lugar en el Centro Cultural Recoleta de Buenos Aires. En ambos casos la imagen se enfoca en el pasado reciente y lo interviene para explorar huellas de la ausencia en el tiempo contemporáneo. Como dije al comienzo, aunque en estos casos haya un foco concentrado en el pasado reciente, la misma dinámica de excavación y recomposición temporal convoca un trabajo de la memoria con tiempos heterogéneos. Así como el pasado y el presente se entrelazan y modifican mutuamente, el trabajo de la memoria se proyecta hacia otras coyunturas temporales donde interviene el régimen mnemónico de alteración.

El presente vaciado de los cuerpos principalmente masculinos de los desaparecidos revela así no solo una ausencia puntual e histórica (el momento de la desaparición), sino cómo ese sujeto retirado del mundo social, familiar y del registro iconográfico continúa faltando y afecta (continúa afectando) la vida de quienes estaban cerca suyo.

Adriana Lestido tiene una sólida trayectoria como fotógrafa por la que obtuvo reconocimiento de la crítica y proyección internacional. Militante en el grupo Vanguardia Comunista en los años setenta, su esposo fue desaparecido en el año 1978. En 1982, trabajando como reportera gráfica para el diario La Voz, de Buenos Aires, tomó una fotografía que la consagró como artista y tuvo una amplia difusión internacional. Titulada Madre e hija de Plaza de Mayo (Imagen 3), se trata de la imagen en la que se observa a una madre de Plaza de Mayo más joven que la edad promedio y a su hija pequeña en una concentración callejera. En 1982 la dictadura militar aún estaba en el poder en la Argentina y el país se encontraba en un proceso de fuerte convulsión política en el que las manifestaciones por los derechos humanos tenían una gran importancia.

Esta imagen, como observa la propia Lestido y remarca Nora Domínguez en el artículo que le dedica (2010), presenta un perfil atípico frente a los retratos de las Madres de Plaza de Mayo. Aquí la madre es joven y no pide por su hijo, que a juzgar por la edad de la hija que la acompaña no podría, en principio, haber sido secuestrado, sino por su compañero; la hija es una niña y ella pide por su padre. Parte del esquema familiar que históricamente ha sustentado la lucha política de las Madres queda así alterado (Domínguez; Lestido). 
Son dos mujeres jóvenes que piden y entre ellas nuevamente aparece el fuera de cuadro: el hombre ausente, padre y compañero, que es el motivo de su reclamo. Vale la pena recalcar que se trata de una figura masculina ausente que se vuelve más visible en la fotografía de Lestido y que repone que no son solo las madres quienes perdieron (a sus hijos) sino también hijas y esposas que han sido privadas de una presencia masculina. El vínculo madrehija, ambas con expresiones de furia y pasión en su reclamo, y sosteniéndose mutuamente, queda resaltado pero con él también cobra dimensión esa figura, también presumiblemente joven, que no está en el conjunto.

Como observa Nora Domínguez (2010), esa ausencia "fundacional" le permitió a Adriana Lestido continuar en su producción fotográfica posterior trabajando bajo un modelo análogo: el de la ausencia masculina que ella misma padeció con su compañero luego de que fuera secuestrado por la dictadura argentina. Ese trabajo a partir de una figura invisible una vez más convoca al fuera de cuadro que señalamos al comienzo del artículo; como también lo señalé al principio, el formato de patchwork, en el que siempre hay partes que faltan y fragmentos que recombinar o montar también puede reconocerse en la obra fotográfica de Lestido. Los pañuelos, los carteles y los nombres escritos en ellos (Fernando, Marcelo), así como el término "familiares" completan la información necesaria para reconocer el contexto de lucha política y lazos de familia en el que transcurre el reclamo.

Quiero continuar observando otra serie de Lestido titulada Mujeres presas (1991-1993), realizada ya durante un régimen democrático y que puede conectarse con esta imagen fundacional de su producción. Según la misma fotógrafa cuenta, luego de tomar la fotografía de 1982, advirtió la importancia de la figura masculina ausente y decidió continuar explorándola. Gran parte de su producción ha tomado como eje imágenes de mujeres en distintos contextos: mujeres huérfanas, mujeres presas, madres adolescentes, madres e hijas.

En todos los casos se reconoce un sujeto ausente que a la vez hilvana la serie y permite elaborar su significado. Como señala Valeria Bula ("Capturar lo invisible"), al realizar la serie mujeres presas, Lestido supo que estas mujeres, que debido a la legislación argentina pueden tener consigo a sus hijos en la cárcel hasta la edad de cuatro años (y por eso son fotografiadas con ellos), suelen ser abandonadas al ingresar en prisión por sus compañeros o parejas, que casi nunca las visitan.

No obstante y quizás para inscribir la memoria en el cuerpo, vemos que ellas llevan tatuados los nombres de sus compañeros. La persistencia de esta presencia-ausente evoca la búsqueda de las mujeres de Calama, que no olvidan y mantienen viva la excavación.

Si miramos las imágenes con atención podremos reconocer los nombres de Darío, Claudio (inscripto en el brazo de la hija) y Andrés, cada uno de ellos tatuado en los brazos de estas tres mujeres presas (o sus hijas) que exhiben con orgullo sus cuerpos escritos (Imágenes 4, 5 y 6). Son cuerpos terrenales y cuerpos privados de la libertad, encerrados en la cárcel que exhibe sus huellas en los rostros y en el espacio al que están confinadas. Privadas como en Madre e hija de Plaza de Mayo de la presencia de hombres, que solo aparecen como nombres tatuados pero no son visibles en la mayoría de las imágenes de la serie, las mujeres presas exhiben un régimen de imagen y memoria en el que lo invisible cobra una dimensión corporal y escrita: la grafía de los nombres ausentes emerge en la piel como una huella indeleble que revela precisamente a quien no está. Darío, Claudio, Andrés no aparecen en ninguna foto. Las imágenes sin embargo parecen incluso ir un poco más allá: 
los tatuajes muestran casi provocativamente que hay (o hubo) hombres junto a estas mujeres, pero que ahora están ausentes.

Los cuerpos, como en Nostalgia de la luz, participan de un régimen temporal complejo: están presos, confinados al estado de excepción característico de la cárcel, sumidos en el régimen cronológico carcelario, pero portan huellas de una vida anterior y del vínculo que une a las mujeres con sus compañeros afuera de la prisión, acaso con una carga de futuro.

Si en Nostalgia de la luz los cuerpos permitían reponer pequeños fragmentos de un pasado ausente es porque funcionaban por su capacidad archivística (Sekula, 2003) en tanto almacenes de información. Se trata de información genética, traumática, histórica; datos sobre el modo de morir recuperado en los cuerpos por las heridas de bala y los huesos astillados que iluminaba una de las zonas que las mujeres de Calama procuraban contestar: la pregunta por la muerte de sus familiares, la certeza necesaria de que están muertos para separar cuerpo y persona y hacer el duelo.

Por último, a diferencia del film de Guzmán, aquí se trata de cuerpos vivos, materia viviente y, en algunos casos, con hijos que las acompañan en la cárcel. Las imágenes revelan formas de vida (celdas, ropa, "familia", prácticas). Esa materia viviente es la que la cárcel controla y la sociedad -pero sobre todo los hombresabandona a su suerte. Los hombres están ausentes porque el régimen carcelario así lo regula, pero también están ausentes por elección propia. El circuito de Lestido que comienza con la imagen de los cuerpos ausentes, secuestrados por la dictadura, se extiende a otros cuerpos masculinos ausentes en la economía de la prisión. Su trabajo de exploración acude a los cuerpos femeninos para exhibir en sus ausencias también una presencia afirmativa: cuerpos y rostros que sostienen la mirada frente a la cámara y muestran una dignidad que, aunque solitaria, se revela vital y resistente.

Quiero terminar refiriéndome brevemente a los fotomontajes de Gustavo Germano incluidos en la muestra Ausenc'as que también trabajan sobre memoria, imagen, trauma y ausencia. Como señalé al comienzo, Germano centra su trabajo en un eje temporal que confronta presente y pasado a partir de los años setenta y como en todos los casos, indaga la supervivencia, el afterlife de esas imágenes y la proyección de los cuerpos ausentes en los de quienes los sobrevivieron. El título de la muestra, que "desaparece" parte de la grafía de la letra i y mantiene solo el punto, refiere esa configuración. También como en los ejemplos anteriores, la familia ocupa un lugar central, ya que los fotomontajes recuperan escenas domésticas donde los desaparecidos todavía estaban y las contrastan con el mismo escenario casi treinta años después. Las cosas, como en Guzmán, cumplen aquí una función heterocrónica: paisajes, muebles, interiores de viviendas y vestimenta proveen el marco para que la ausencia adquiera una evidencia tangible en el contraste entre dos temporalidades apartadas entre sí.

Como observan Andrea Giunta y Celina Van Dembroucke el trabajo de Germano, centrado en la figura de Eduardo, su hermano mayor desaparecido durante la dictadura militar argentina y de otras personas, tiene un componente performativo reconocible en la necesidad de pedir la colaboración de los familiares y de organismos de Derechos Humanos de la Provincia de Entre Ríos, de donde es la familia de Germano, para la composición de las imágenes más recientes en las que se reconstruye el escenario y las personas que participaban de esas imágenes. Así, los familiares que estaban en las fotografías de los años setenta fueron invitados a posar nuevamente en esos mismos escenarios treinta años más tarde (Giunta; Van Dembroucke). No se trata por lo 
tanto solo de la imagen, sino también de un acto de memoria implícito en la composición de las imágenes. El paso del tiempo es aquí tal vez más visible que en cualquiera de las otras imágenes observadas. El contraste entre modas, decoración, la ropa y los objetos de las personas retratadas en cada una de las fotografías se vuelve más visible al exhibirlas una al lado de la otra.

Quizás lo más revelador del trabajo de Germano sea la capacidad de referir no solo a la dialéctica ausencia/presencia, sino a "las vidas que el desaparecido no vivió" (Giunta). El proyecto logra capturar, en el vacío de la representación, el vaciamiento de la experiencia y de lo viviente, esa materia inasible que consiste en el transcurrir de la vida y que fue secuestrada junto a las personas. Estas imágenes consiguen mostrar así las vidas sesgadas junto a los cuerpos (valiéndose de ellos y de los cuerpos de sus deudos, que exhiben las marcas del tiempo). De este modo la instalación rinde tributo no solo a quienes pagaron con su vida la violencia política del pasado reciente, sino también a quienes los rodeaban y se vieron privados de su compañía viviente a lo largo del tiempo (Imágenes 7 y 8 ).

Notas

1. "La imagen a menudo tiene más memoria y más porvenir que el ser que la mira" (Didi-Huberman, 2008, p. 12).

2. Una foto de un personaje del siglo XIX, como la abuela de Kracauer, queda fija en vestimentas que se vuelven obsoletas a los ojos de observadores contemporáneos. Cada nueva observación revive el pasado y lo "vuelve más pasado" (al tiempo que lo vuelve también presente, al insertarlo en un momento contemporáneo en el que brilla).

Bibliografía

Bhabha, H. (2013). Nuevas minorías, nuevos derechos. Notas sobre cosmopolitismos vernáculos. Buenos Aires: Siglo XXI.

Beceyro, R. (2004). Ensayos sobre fotografía. Buenos Aires: Paidós.

Benjamin, W. (2005). "Excavation and Memory". En Selected Writings, Vol. 2, part 2 (1931- 1934), "Ibizan Sequence", 1932, ed. by Marcus Paul Bullock, Michael William Jennings, Howard Eiland, and Gary Smith, Cambridge, Mass.: Belknap Press of Harvard University Press, p. 576 Cadava, E. (1997). Words of Light: Theses on the Photography of History. Princeton: Princeton UP.

Derrida, J. (2006). Memories: for Paul de Man. New Haven: Yale University Press.

Didi-Huberman, G. (2006). Ante el tiempo. Buenos Aires: Adriana Hidalgo.

Domínguez, N. (2010). "Mirar madres. Adriana Lestido: espacios, rostros, afectos". Recuperado de Mora 16.1. http://www.scielo.org.ar/scielo.php?pid=S1853-001X2010000100005\&script=sci_arttext Feld, C. y Stites Mor, J. (comps.) (2009). El pasado que miramos. Memoria e imagen ante el pasado reciente. Buenos Aires: Paidós.

Giorgi, G. (2014). Formas comunes: Animalidad, cultura, biopolítica. Buenos Aires: Eterna Cadencia. 
Giunta, A. (2010). “Politics of Representation. Arts \& Human Rights”. E-misférica 7.2.

Hartog, F. (2012). Régimes d’historicité. Présentisme et expériences du temps. París: Seuil.

Hirsch, M. (2012). The Generation of Postmemory: Writing and Visual Culture after the Holocaust. Nueva York: Columbia UP.

Huyssen, A. (2003). Present pasts. Urban Palimsests and the Politics of Memory. Stanford: Stanford University Press.

Koselleck, R. (2004). Futures past. On the semantics of historical time. New York: Columbia UP.

Kracauer, S. (1995). The Mass Ornament. Weimar Essays. Cambridge: Harvard UP.

García, L. y Longoni, A. (2013). “Imágenes invisibles. Sobre las fotos de desaparecidos” en Blejmar, J., Fortuny, N., y García L. Instantáneas de la memoria. Fotografía y dictadura en Argentina y América Latina. Buenos Aires: Libraria.

Richard, N. (2010). Crítica de la memoria (1990-2010). Santiago: Ediciones Universidad Diego Portales.

Van Dembroucke, C. (2010). “The Absence Made Visible: The Case of Ausenc as, Gustavo Germano's Photographic Exhibition”. En InTensions 4, Toronto: York UP.

Sekula, A. (2003). "El cuerpo y el archivo”. En Picazo, Gloria y Ribalta, Jorge (eds.), Indiferencia y singularidad. Barcelona: Gustavo Gili.

Abstract:

This article proposes a comparison of representations of recent traumatic past in Argentina and Chile using the testimonies collected in the film Nostalgia for the Light by Patricio Guzmán, the photography series Lo que se ve (1979-2007) by Adriana Lestido, and two photographic compositions by Gustavo Germano belonging to the series Ausencias. Both the film and the photographs refer to absent traces (absent bodies), killed during Military Dictatorships in Argentina and Chile, using the memories and testimony of surviving relatives. The work proposes to analyze the temporal traumatic regime of disappeared bodies and their contrast with affective memory, examine the iterative, heterochronic temporal condition of trauma in the contemporary scopic Latin American regimes, and interrogate the uses of mnemonic archive as a visual (political) intervention- (artistic) installation.

Key words:

memory - time - image - film - photography.

Resumo:

Este artigo propõe comparar representações do passado traumático recente na Argentina e no Chile a partir de testemunhos reunidos no filme Nostalgia de la luz de Patricio Guzmán, na série fotográfica Lo que se ve (19792007) de Adriana Lestido e em duas fotomontagens de Gustavo Germano, pertencentes à série Ausencias. 
Tanto o filme como as imagens evocam os vestígios ausentes (os corpos ausentes), executados pelas ditaduras militares na Argentina e no Chile, a partir da evocação e presença dos familiares sobreviventes. O trabalho propõe analisar o regime temporal traumático dos corpos desaparecidos e seu contraste com a memória afetiva, além de examinar a condição temporal interativa heterocrônica do trauma nos regimes escópicos sulamericanos contemporâneos e interrogar os usos do arquivo mnemônico como intervenção-instalação visual.

Palavras chave:

memória - tempo - imagem - cinema - fotografia.

Imágenes, trauma, memoria: miradas del pasado reciente en obras de Patricio Guzmán, Adriana Lestido y Gustavo Germano fue publicado de la página 107 a página122 en Cuadernos del Centro de Estudios de Diseño y Comunicación № 61 